Jnl of Ecclesiastical History, Vol. 68, No. 4, October 2017. (C) Cambridge University Press 2017784 This is an Open Access article, distributed under the terms of the Creative Commons Attribution licence (http://creativecommons.org/licenses/by/4.o/), which permits unrestricted re-use, distribution and reproduction in any medium, provided the original work is properly cited.

doi:10.1017/Soo22046917000665

\title{
The 'Affair of the Photographs': Controlling the Public Image of a Nineteenth-Century Stigmatic
}

\author{
by TINE VAN OSSELAER \\ University of Antwerp \\ E-mail: tine.vanosselaer@uantwerpen.be
}

The article focuses on an episode concerning the photographs of the famous Belgian stigmatic, Louise Lateau. Examining the events leading up to the bishop's decision to restrict the circulation of her portrait, it becomes clear that the 'affair' of I 877 was as much about creating her public saintly image as it was about controlling it. Studying the ecclesiastical response to grassroots initiatives adds a more religious perspective to the young field of celebrity studies and offers a more complex view on sanctity, and the role of the media and modern techniques in its creation, use and misuse.

\section{Louise's pictures}

On 26 October 1877 the vicar general of the bishop of Tournai sent the following message to Fr Paul Niels of Bois-d'Haine, a small village in the Belgian province of Hainaut:

the act of taking Louise Lateau's photograph, an act that Mgr. the Bishop in no way authorised for the purpose of any kind of publicity whatsoever, but especially for the publicity in which you are, so we have been assured, very willing to engage,

ALL $=$ Archives of Louise Lateau, J. 11, images and photographs, 1, Seminary of Tournai; ASJF = Archives of the Society of Jesus of Flanders, Kadoc (Documentation and Research Centre for Religion, Culture and Society), KU Leuven, Belgium.

The research upon which this article is based was conducted with the generous support of the ERC (Starting Grant, 2014, 'Between Saints and Celebrities: the Devotion and

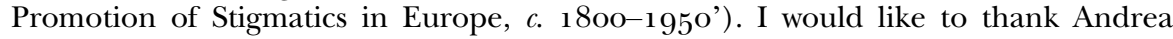
Graus, Leonardo Rossi, Bill Christian and Gábor Klaniczay for their comments upon previous versions. I am also most grateful to the Ruusbroec Institute and the Archives of the Seminary of Tournai for granting permission to use the illustrations included in this article. 
is diametrically opposed to the reserve that the Holy See imposes on itself and prescribes us on such occasions. ${ }^{1}$

As a consequence, the note read, Niels was not to be surprised by the rigour of the measures that the bishop deemed fit to impose, 'conform[ing to] the instructions of the Holy See'. Under threat of a suspension a divinis, Fr Niels was to send to the bishop all the pictures in his possession (as well as those that he had handed out) and 'the negative plates of every kind, reproducing in one way or another the features of Louise Lateau' within three days. ${ }^{2}$ A similar demand was sent to the French priest, Charles Ducoulombier, a teacher at the Tourcoing College, who had assisted during the photoshoot. Ducoulombier was also forbidden to see Louise again or to say mass in Bois d'Haine. ${ }^{3}$

Louise did not need any additional publicity to reach the public eye. In autumn 1877 she was already one of the best-known stigmatics of her time. Her case was fiercely discussed in public debates about medicine and religion, an object of ridicule for anti-Catholic liberals and a symbol of hope to Catholics, who felt comforted by her visible stigmata and interpreted them as a sign of God's presence on earth. So why did the bishop (who was convinced of her saintly character) resort to such stern measures regarding the photographs of a female stigmatic? This article will examine the events leading up to his ordinances in an attempt better to understand religious celebrities and the Catholic Church's attempts to control (and use) their fame.

Celebrity studies is a relatively young field, and apart from those scholars working on the sacralisation of celebrities, most research takes a rather secular perspective. The few scholars who have addressed the interaction between sanctity and celebrity have mainly done so by focusing on what happened after the demise of figures such as Thérèse of Lisieux or Padre Pio. ${ }^{4}$ Furthermore, they have primarily focused on the twentieth

1 'Le fait du tirage de la photographie de Louise Lateau, fait que Monseigneur l'Évêque n'a nullement autorisé en vue d'une publicité quelconque, mais surtout cette publicité même à laquelle vous êtes, assure-t-on, tout prêt à vous prêter, est diamétralement contraire à la réserve que le saint siège s'impose et nous prescrit en pareille occurrence': Désiré Hallez, vicar general, to Fr Paul Niels, ALL, A.6, cahiers abbé Niels-imprimés (1876-81) (Cahiers), 1877, 221.

${ }^{2}$ Ibid.

3 Also involved in the undertaking were M. Paul Vrignault, former head of the Ministry of Foreign Affairs in Paris and Consul Général de France, and Marie and Pauline De Beukelaer, two laywomen from Antwerp: ibid. 196, 220.

4 Sophia Deboick, 'Céline Martin's images of Thérèse of Lisieux and the creation of a modern saint', in Peter Clarke and Tony Claydon (eds), Saints and sanctity, Woodbridge 201 1, 376-89; Peter Jan Margry, 'Merchandising and sanctity: the invasive cult of Padre Pio', Journal of Modern Italian Studies vii/1 (2002), 88-115. Aviad Kleinberg, however, suggests that the (living) saints of the Middle Ages should be seen as the celebrities of their time: 'Are saints celebrities? Some medieval Christian examples', Cultural and Social History viii (2011), 393-7. 
century, as the era of the mass media, and adopted a top-down perspective, studying, for example, strategic canonisations or devotional-promotional practices. ${ }^{5}$ The interaction between the lay public, the clergy and the ecclesiastical authorities concerning the creation of a public image and its use and misuse has rarely been studied. The 'affair of the photographs', as the episode came to be known, demonstrates how the publicisation of religious personalities was also under discussion in the second half of the nineteenth century, and shows that the impact of the medium was of central importance. This article will examine the ecclesiastical response to grassroots initiatives and trace what issues were at stake in October 1877 .

The affair was as much about creating a public - saintly - image as it was about controlling it. Studying this case thus allows us to see how the new photographic techniques were being used to create a public image and document what contemporaries saw as sanctity. Photography was still at a rather early stage at the time but, as Thérèse Taylor has remarked, it had an important influence on contemporary 'holy' women: 'The camera's ability to record reality and associated technological developments which led to the proliferation of commercial prints, created a new market for religious pictures. Photographic representation also promoted a fixation on appearances, and a reliance upon aesthetic standards, as an evidence of moral worth. ${ }^{6}$ In other words, as suggested by Claude Langlois, photography was a means of providing a portrait of the saint and demonstrating the sanctity of the figure. 7 Taking a photograph also implied the selection (of objects, poses and image, etc.) and, to a certain extent, manipulation of the photographed object better to serve the needs of those for whom it was intended. ${ }^{8}$ The first point of relevance is therefore the aims of the Boisd'Haine photographers - and this begins with an analysis of how the hands of Adeline Lateau (Louise's sister) were caught on camera.

\section{Adeline's hands: staging sanctity}

In order to understand the incentives for those involved in taking Louise's photographs, it is necessary to return to early October 1877 . At that time

5 Oliver Bennett, 'Strategic canonisation: sanctity, popular culture and the Catholic Church', International Journal of Cultural Policy xvii/4 (2011), 438-55; Donn James Tilson, The promotion of devotion: saints, celebrities, and shrines, Champaign, IL 2011.

6 Thérèse Taylor, 'Images of sanctity: photography of Saint Bernadette of Lourdes and Saint Thérèse of Lisieux', Nineteenth-Century Contexts xxvii/3 (2005), 269-92 at p. 269.

7 Claude Langlois, 'Photographier des saintes: de Bernadette Soubirous à Thérèse de Liseux', in Michèle Ménard and Annie Duprat (eds), Histoire, images, imaginaires (fin XVe siècle-début XXe siècle), Le Mans 1998, 261-73 at p. 261.

${ }^{8}$ On photography as a practice see Maria Giulia Donderdo, Le Sacré dans l'image photographique: études sémiotiques, Paris 2009. 
Louise Lateau was already famous in Belgium and internationally. As the daughter of a railway worker (who had died soon after her birth), nothing destined her for the public eye until she started to display Christ's wounds in April 1868.9 The ecstatic episodes that she experienced each Friday were well known: they were elaborately commented upon in newspaper articles and booklets, and the faithful could witness these episodes by visiting the house where she lived with her two sisters, Adeline and Rosine. ${ }^{10}$ Rosine stubbornly protested against Louise's picture being taken, even after Marie and Pauline De Beukelaer had obtained permission from the bishop of Tournai, Edmond Dumont, on ${ }_{15}$ February ${ }_{1876 .}{ }^{11}$ Photographs of Louise were in high demand after the artist Alexandre Thomas had displayed a painting of her in spring $1876 .^{12}$ Rosine only agreed to the photography after intense persuasion and on condition that the photographer was a member of the clergy. Subsequently, a Jesuit, Ernest Lorleberg, ${ }^{13}$ consented to participate in the undertaking, and on 3 October 1877 a small group travelled from Antwerp to Bois-d'Haine.

Three of the people involved wrote elaborate accounts of what happened over the following days. The diaries of Fr Niels, an exceptionally rich source of information about Louise's life, amply document the events in 1877 . The photographer, Lorleberg, and Charles Ducoulombier also documented the episode. Most of these accounts seem to have been written after the bishop intervened, and they include descriptions, justifications of their actions and the correspondence (copied) between them and the vicar general of the diocese. ${ }^{14}$ Apart from some minor references in

9 Gaspard-Joseph Labis, then bishop of Tournai, created a diocesan commission, probably at the instigation of Dechamps (4 Sept. 1868). The commission did not publicly announce their decision, although its members had a positive impression: E. Collard, 'Lateau, Louise', in Roger Aubert (ed.), Dictionnaire d'histoire et de géographie ecclésiastiques, $\mathrm{xxx}$, fasc. 177-8a, Paris 2009, 811-13. On the more critical stance of one of its original members, P. Edouard Huchant, see Maria Didry and A. M. Wallemacq, La Stigmatisée de Bois-d'Haine, Louise Lateau, $5^{\text {th }}$ edn, Bois-d'Haine 1993,83 .

${ }_{10}$ Louise had stopped eating on 31 March 1871 . After 1876 she no longer had the strength to leave the house and after 1879 she had to remain in bed. See Paula Kane, 'Stigmatic cults and pilgrimage: the convergence of private and public faith', in Tine Van Osselaer and Patrick Pasture (eds), Christian homes: religion, family and domesticity in the Igth and 2oth century, Leuven 2014, 104-25.

${ }^{11}$ ALL, A.6, cahiers, $1877,218$. 12 Ibid.

13 Ernest Lorleberg ( $1835^{-1908)}$, born in Aschersleben in Germany, converted to Catholicism and moved to Antwerp after his noviciate. He was a professor of German at the St Ignatius Institute in Antwerp: A. H., 'Een vriend van Jesus' H. Hart', Bode van het Heilig Hart (1909); 'P. Ernestus Lorleberg', Litterae Annuae Provinciae Belgicae Societatis Jesu: 19o8-I2, Roeselare 1922, 272-5.

${ }^{14}$ Archives of individual Jesuits, ASJF, 4.2.6: 1595 Ernest Lorleberg; 14475: 'Mémoire sur les photographies de Louise Lateau avec supplément de quelques-unes 
biographies of Louise, these sources have never been thoroughly studied. This is even more remarkable given that they can be compared to the pictures which - against all odds - survived the episcopal intervention.

The reflections of these three male members of the clergy offer an insight into what they believed to be their mission in photographing the young stigmatic woman. Tellingly, three types of pictures were taken: portrait pictures of Louise (and her sisters), group photographs of the young women standing outside their house and pictures of Louise in ecstasy. In total, there were twenty-one negatives. While pictures of traditional saints had been circulating on devotional cards for centuries, in taking portrait photographs of a young girl who was assumed to have experienced supernatural phenomena, Lorleberg and his assistants were following a rather new trend.

More specifically, the events in Lourdes and its development as a highly commercialised location had encouraged the exploration of new photographic means for the promotion of the site and the cult. The young visionary Bernadette Soubirous had her picture taken in the 1860 os to meet the demand of the Lourdes pilgrims. She was photographed in a studio, praying and re-enacting the Marian apparitions. As Claude Langlois has pointed out, in an attempt to increase the level of exoticism, Bernadette was photographed in the traditional dress of her region to enhance her appearance as an unspoiled young girl from the countryside. ${ }^{15}$

Similar clues to Louise Lateau's humble background were also present in the images made of her: she wore a dress with an apron, her dressmaker's scissors were hanging from her belt and she wore small black fingerless gloves to cover the stigmata. Those who saw these pictures without knowing who the person was, were thereby given small clues (fingerless gloves, scissors) to uncover the identity of the stigmatised dressmaker. In this respect, the photograph echoes more traditional saintly iconography, in which saints are recognisable on the basis of an emblem. Similarly, the group pictures of Louise, her sisters and their pupil Egida had an idealising function and, as Ducoulombier explicitly noted, were intended to document the peaceful rural life that they led in their cottage. ${ }^{16}$

Given the relative rarity of photographs at the time, Lorleberg was surprised at the ease with which Louise posed:

she does not seem to be nervous or impressionable like other persons of her sex. She poses without head support with the tranquillity of someone who has never

de ses paroles dites à l'auteur'; 'Affaire des photographies représentant Louise Lateau', M. l'Abbé Ducoulombier, 1877-78, ALL, B.4, documentation diverse, 8; 'L'histoire de la photographie de Louise Lateau', ALL, A.6, cahiers, $1877,194$.

${ }_{15}$ Claude Langlois, 'La Photographie comme preuve', Histoire des sciences médicales xxviii/4 (1994), 325-36. See also Taylor, 'Images of sanctity', 270-1, 275.

${ }_{16}$ ALL, A.6, cahiers, $1877,196,197,199$. 


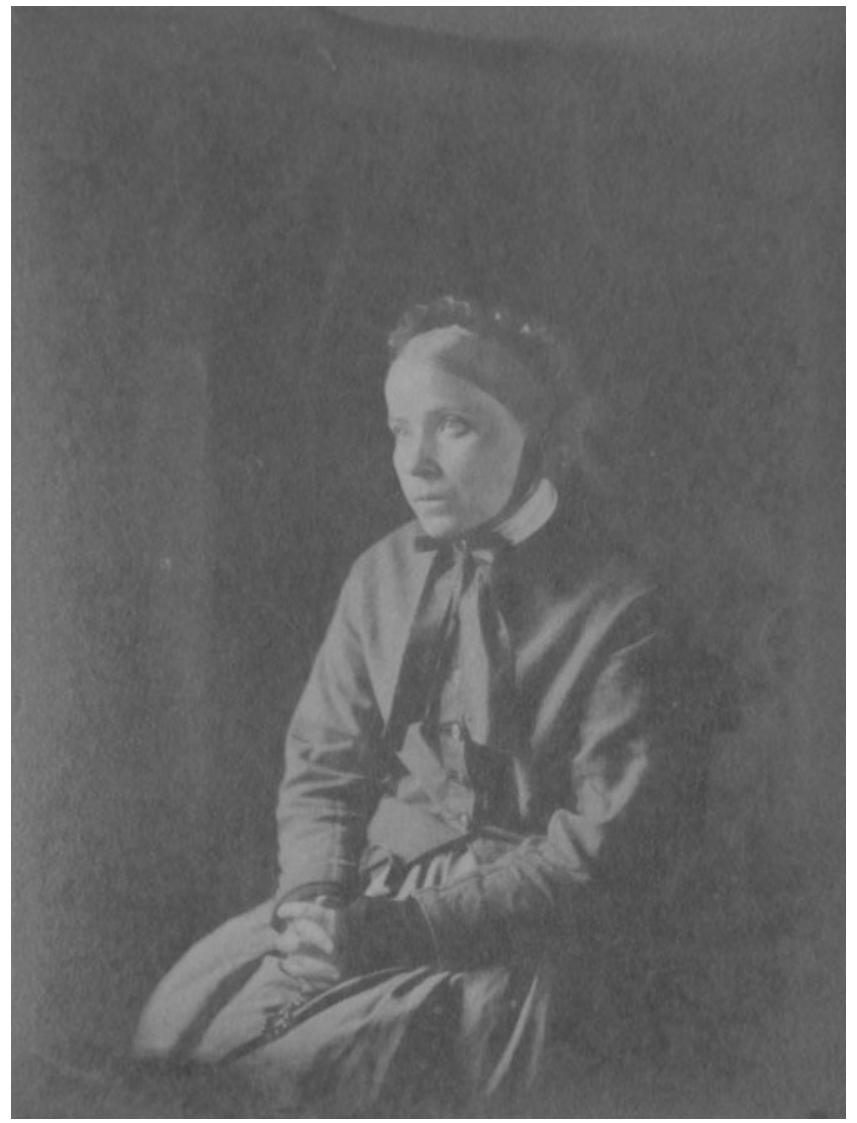

Figure 1. Louise Lateau praying, October 1877 (photograph no. 10 in series taken by Ernest Lorleberg), ALL.

done anything else. Anyone who remembers how impressed he was when his first portrait was taken will understand that this shows in Louise a calmness that one rarely finds, even among men. ${ }^{17}$

He liked best photograph no. 10 (see fig. 1), which showed Louise seated with her rosary and wearing fingerless gloves, praying while staring at a crucifix. According to Lorleberg, her figure was 'transformed' and the

17 'Elle ne paraît pas être nerveuse et impressionnable comme les personnes de son sexe. Elle pose sans appui-tête avec la tranquillité d'une personne qui n'aurait jamais fait autre chose. Quiconque se souvient, comment il était impressionné quand on lui faisait son premier portrait, comprendra que cela dénote chez Lse un calme et un sang-froid qu'on trouve rarement, même chez les hommes': ASJF, Lorleberg, 5 . 
gaze, directed upwards, 'illuminated'. He noted that while she was not in ecstasy when the photograph was taken, anyone who saw the picture might think that she was. In his opinion, this photograph best captured the saintly image of Louise. ${ }^{18}$

Unlike the Lourdes photographs, Louise's were not only portraits or studio re-enactments of the reported events. The Lorleberg group also photographed Louise in ecstasy and managed to do what, according to Fr Niels, had been impossible for painters to do because 'the length of an ecstatic experience was too short and the expression of the figure changed too often for a painter to be able to capture her traits without recourse to photography'. ${ }^{19}$ Nevertheless, a photographer faced similar problems. To generate a good effect, the person posing for a picture needed to keep still for some time (hence the head support). When Louise went through Christ's Passion or experienced other moments of ecstasy, she did not remain calm:

To capture her during the effusion of a powerful emotion was the test that naturally came to mind, but how could one catch a smile that formed and changed so easily on the lips of the ecstatic under the influence of the words that seemed to strike her and that she revealed through the expression on her face, or through various utterances...? It was a difficult task, but we tried it nonetheless by reciting the Hail Mary in a certain way; we thus managed to maintain the same smile and the same expression on Louise's face. ${ }^{20}$

While the series of pictures create the impression of a genuine 'capturing' of Louise's ecstasy, they are not photographic 'proof' of a spontaneous event (which was the case with the Friday ecstasies). ${ }^{21}$ The photographed episodes were induced and staged; for example, Louise's bed was pushed closer to the window and a second pillow was added. In addition, her sister Adeline held up a white sheet next to Louise's face better to illuminate the small room, which had limited direct light. As a result, her hands

18 'figure transformée', 'le regard porté en haut est illuminée', 'Le cliché est faible mais fidèle, c'est à mon avis le seul vrai portrait de Louise, portant son cachet de sainteté': ibid. 7 .

19 Niels to Mgr [Dumont], 7 Apr. 1876, ALL, A.6, Niels, 1876, 72.

20 'La prendre donc dans l'effusion d'un grand sentiment était une épreuve qui venait naturellement à l'esprit mais comment fixer un sourire qui se forme et se modifie si facilement sur les lèvres de l'extatique sous l'action des paroles qui semblent la frapper et qu'elle traduit par l'expression de sa physionomie, ou par des paroles différentes ... Le problème étant difficile nous le tentâmes pourtant en récitant d'une manière l'Ave Maria; nous parvînmes ainsi à maintenir le même sourire et la même expression, sur le visage de Louise': Ducoulombier report, 5 Oct. 1877, ALL, A.6, cahiers, $1877,197,208$.

${ }^{21}$ The Friday ecstasies were spontaneous, periodic and at a specific location: Sofie Lachapelle, 'Between miracle and sickness: Louise Lateau and the experience of stigmata and ecstasy', Configurations xii (2004), 77-105 at p. 92. 


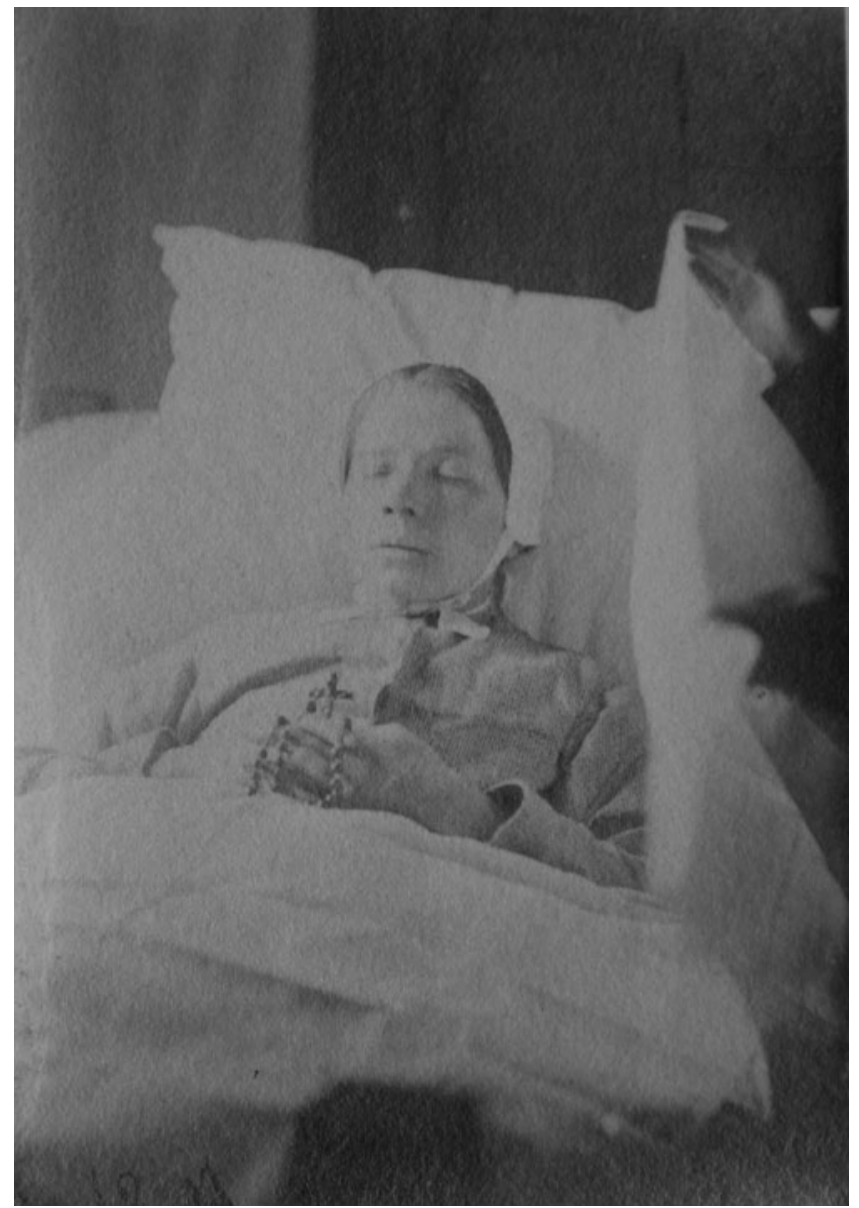

Figure 2. Louise Lateau in bed with her rosary; Adeline's hands can be seen on the right, October 1877 (photograph no. 1 1, Lorleberg), ALL.

can be seen in one of the pictures (see fig. 2 ).${ }^{22}$ Lorleberg was initially kept in the dark about how the ecstasies were triggered (he was asked to leave the room), but Ducoulombier and Niels corresponded extensively on the matter afterwards. Prior experiments had shown that Louise's ecstasies could be provoked by bringing her a bottle of water used for ablution. ${ }^{23}$

${ }^{22}$ Ducoulombier report, 5 Oct. 1877, ALL, A.6, Niels, 1877, 197, 206-7; ASJF, Lorleberg, 11.

23 'Mémoire sur les photographies de Louise Lateau', ASJF, 9. The Passionist, Fr Séraphin, commented critically on such experiments: ALL, A.6, cahiers, $1877,199$. 
Ducoulombier later regretted taking the experiment a little too far ${ }^{24}$ and remarked that he also hesitated at the time of the photoshoot: 'Could I, even in the interest of the work that we were executing, provoke an unaccustomed ecstasy and rapture? Did respect for saintly things not oblige me to abstain?'25 Against all expectations, the ecstasy pictures were successful. Ducoulombier believed that there was

no earthly representation of the divine dénouement of the drama of the Passion that is more moving and more accurate [see fig. 3]. The Christian eye will be able to study in it the agony with all its anguish and the image of death with all the sorrows that accompany it. From that perspective, the photograph will become a sermon that will make saintly souls' tears flow and provide an idea of the torments that our Lord endured for us on the Cross. ${ }^{26}$

This idealisation of Louise's suffering might sound strange to present-day ears. For nineteenth-century Catholics, however, the beauty of pain and its productive, reparatory nature were well known. Through physical and emotional suffering, Louise was a 'victim soul', repenting for the sins of others and society as a whole. Thus, even in her moments of greatest pain - when she suffered through Christ's Passion on Fridays - she was the embodiment of a Christian ideal, a saint in the making. ${ }^{27}$ To those involved, the importance of the photographs could hardly be overestimated: 'Never has photography, which is like God's pen, written such a poem. The imagination of Christian artists has of course been able to conceive an ecstatic ideal, and show on their canvas the splendour of the divine

${ }^{24}$ Ducoulombier therefore asked Niels to return the report on the photoshoot so that he could rewrite certain passages and escape the reproach of 'légèreté aux yeux des inquisiteurs futurs': Charles Ducoulombier to Neils, 26 Nov. 1877, ALL, B.4, documentation diverse, 8 , affaire des photographies. See also Ducoulombier to Niels, 3 Jan. 1878 , ibid.

${ }_{25}$ 'Pouvais-je, même dans l'intérêt de l'œuvre que nous étions en train d'exécuter, provoquer une extase et un ravissement inaccoutumés? Le respect des choses saintes ne m'imposait-il pas l'obligation de m'abstenir?': ALL, A.6, cahiers, 1877,197 . See reports on these experiments in 'Théologie pastorale', Nouvelle Revue théologique x (1878), 394419, esp. pp. 395-401.

${ }_{26}$ 'Je ne crois pas qu'il ait sur la terre une représentation plus émouvante et plus fidèle du dénouement divin du drame de la Passion. L'œil chrétien y pourra étudier l'agonie avec toutes ses angoisses et l'image de la mort avec toutes les douleurs qui l'accompagnent. A ce point de vue, la photographie deviendra une prédication, qui fera couler des larmes aux âmes saintes, et qui donnera une idée des tourments que N.S. a endurés pour nous sur la Croix': Ducoulombier report, Oct. 1877, ALL, A.6, cahiers, $1877,217$.

${ }^{27}$ For the history of pain and Catholic variations see Joanna Bourke, The story of pain: from prayer to painkillers, Oxford 2014; Javier Moscoso, Pain: a cultural history, Basingstoke 201 2; Richard Burton, Holy tears, holy blood: women, Catholicism, and the culture of suffering in France, I840-1970, Ithaca-London 2005; Paula Kane, "She offered herself up": the victim soul and victim spirituality in Catholicism', Church History lxxi/1 (2002), 80-1 19. 


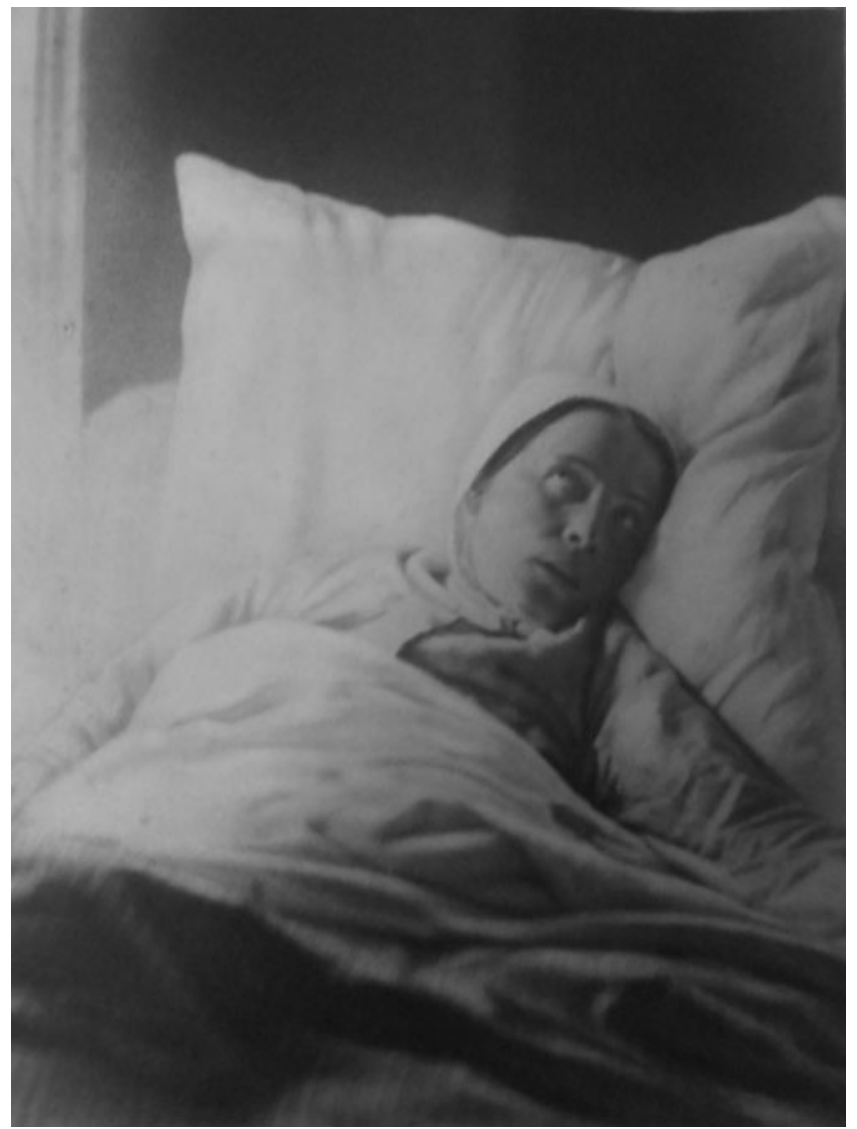

Figure 3. Louise Lateau in ecstasy, October 1877 (photograph no. 23, Lorleberg), ALL.

rays that flow freely on the human face during ecstasy.' They were preserving for the following generations 'the marvellous but mobile illuminations of a transfigured face' without 'recourse to imagination' and 'on paper that does not deceive or invent anything'. ${ }^{28}$ In fact, this set of photographs showed Louise as a prototypical mystic of her time. Nicole Priesching has

28 'Jamais la photographie, qui est comme la plume de Dieu, n'avait écrit un semblable poème. L'imagination des artistes chrétiens avait pu, sans doute concevoir un idéal extatique, et faire resplendir sur leur toile les rayons divins qui se déversent à flots, pendant l'extase, sur le visage humain ... On allait donc enfin pouvoir perpétuer, sans le secours de l'imagination et d'une manière permanente, sur un papier qui ne trompe pas et n'invente rien, les merveilleuses mais mobiles illuminations d'un visage transfiguré': Niels, diary entry, ALL, A.6, cahiers, 1877, 195. 
demonstrated that in the nineteenth century it was primarily the corporeal aspects of the religious experience, rather than the intellectual content, that led these 'ecstatic women' to be regarded as mystics. ${ }^{29}$

The photographic plates still needed some work, but, as the small group packed up, they considered that they had succeeded in documenting Louise's case and in taking the first photograph of someone in religious ecstasy..$^{\circ}$ Lorleberg, however, admitted in his diary that he liked Louise better in her 'natural state'. He had felt ill at ease when he first saw Louise in ecstasy as it was strange to see her act 'like an automaton', in a manner 'reminiscent of a nervous illness'. He was none the less full of praise for the humble composure of the girl: 'Veneration, thus, I told myself, for natural Louise'. $3^{1}$ To understand Lorleberg's unease, it has to be recognised that these photographs could be read in a way that suggests hysteria rather than sanctity. More specifically, the poses of the Crucifixion and the Passion had been linked to fits of hysteria by the scholars of La Salpêtrière in Paris. Louise Lateau had already been associated with hysteria several times, with one of the most vehement attacks published only two years earlier, in 1875 , by the French neurologist Désiré Bourneville. The third chapter of his book, Louise Lateau; ou, La stigmatisée belge, stated, for example, that 'Louise Lateau is a hysteric: a clinical demonstration.' ${ }^{2}$ A year later, with Paul Regnard, he published the first volume of the Iconographie photographique de la Salpêtrière, capturing the various moments of a hysterical fit in photographs and alluding to the case of Louise Lateau when explaining some of the poses (such as the Crucifixion pose). Bourneville, Regnard and Charcot used photography to experiment, catalogue and educate, and they were also using new photographic means to pathologise the 'new mystics'. 33 It seems that even in Belgium, where Louise had been the object of two medical

${ }^{29}$ Nicole Priesching, 'Mystikerinnen des 19. Jahrhunderts - ein neuer Typus?', in Waltraud Pulz (ed.), Zwischen Himmel und Erde: körperliche Zeichen der Heiligkeit, Stuttgart 2012, 79-97.

$3^{\circ}$ 'Mémoire sur les photographies de Louise Lateau', ASJF, 57.

$3^{1}$ 'comme une automate ... cela ressemblait tant à une maladie nerveuse ... Vénération donc, me disais-je, pour Louise naturelle': 'Mémoire sur les photographies de Louise Lateau', ASJF, 15 . On the clergy's use of the pathologisation of religion as a means to counter strange phenomena (such as stigmatisation, apparitions and possession) of apocalyptic Catholicism of the 1860 and 1870 (decline of the temporal power of the Pontifical States and trauma of the French Commune) see Hervé Guillemain, Diriger les consciences, guérir les âmes: une histoire comparée des pratiques thérapeutiques et religieuses (I 830-1939), Paris 2006, at p. 138 for the importance of the Louise Lateau case.

$3^{2}$ D. Bourneville, Louise Lateau; ou La stigmatisée belge, Paris 1875 .

33 Georges Didi-Huberman, Invention de l'hysterie: Charcot et l'iconographie photographique de la Salpêtrière, Paris 1982, 33; Sander Gilman, Seeing the insane: a visual and cultural history of our attitude towards the mentally ill, New York 1982, 164, and 'The image of the hysteric', in Sander Gilman, Helen King, Roy Porter and others (eds), Hysteria beyond 
examinations (in 1868-9 and $1874^{-5}$ ) - which had not come to any conclusions but had been openly commented upon in the press none the less - such associations were not easily ignored. ${ }^{34}$ Every picture of Louise in a pose similar to one that the doctors of La Salpêtrière had defined as a state of hysteria made her vulnerable to such accusations. However, for the bishop of Tournai, it was the idea that they served to create publicity that was the major reason for his stern response.

\section{'Premature and untimely': the bishop's response}

On the other hand, you seem to have believed, Mgr., that I intended to publish and distribute the portrait of Louise. I can affirm once more, in the sincerity of my conscience, that this thought never entered my mind. 35

From the first appearance of the stigmata on Louise's body, on 24 April 1868, the Belgian bishops had adopted an attitude of reserve. Nevertheless, they had not stopped frequent visits by the public and even went to Bois-d'Haine to see for themselves..$^{6}$ The bishop of Tournai had also commissioned a painting of her in 1876 by Alexandre Thomas, which showed the young girl in a state of calm, contemplating the crucifix, with little trace of the stigmata (see fig. 4). This seems to have been a deliberate choice, as the Brussels artist had also produced a smaller portrait of Louise in ecstasy with bloody traces of the head wound visible and with Louise's mouth slightly open (see fig. 5). Given the fact that Niels had mentioned the immediacy of photography as necessary to capture Louise's features during ecstasy, it is interesting to note that Alexandre Thomas had indeed succeeded in painting her in that

Freud, Berkeley 1993, 345-452 at p. 352; Rae Beth Gordon, De Charcot à Charlot: mises en scène du corps pathologique, Rennes 2013.

34 The first by members of the diocesan commission, the second by members of the Académie Royale de Médecine de Belgique. See Gábor Klaniczay, 'Louise Lateau et les stigmatisés du xixème siècle', in Gábor Klaniczay (ed.), Discorsi sulle stimmate dal medioevo all'età contemporanea, Archivio italiano per la storia della pietà xxvi (2013), 279-319; Lachapelle, 'Between miracle and sickness'; Wannes Dupont, 'Free-floating evils: a genealogy of homosexuality in Belgium', unpubl. PhD diss. Antwerp 2015, 139-43.

35 'D'un autre côté, vous avez paru croire, Mgr., que j'avais l'intention de publier et de répandre le portrait de Louise. Je puis vous affirmer de nouveau, dans la sincérité de ma conscience que cette pensée n'est jamais entrée dans mon esprit': Neils to Dumont, ALL, A.6, cahiers, 1877,224 .

$3^{6}$ Dechamps visited her in August 1868, Mgr Labis on 2 Mar. 1869 : Eugène Collard and Jeanne Marie Dehoux, La Petite Couturière de Bois-d'Haine: Louis Lateau (I 850-I883), Bois-d'Haine 1996, 35; Didry and Wallemacq, La Stigmatisée de Bois-d'Haine, 71-3, 83-5; E. Collard and J. M. Dehoux, Notre Louise ... à petites traits, Mons 1996, 12. 


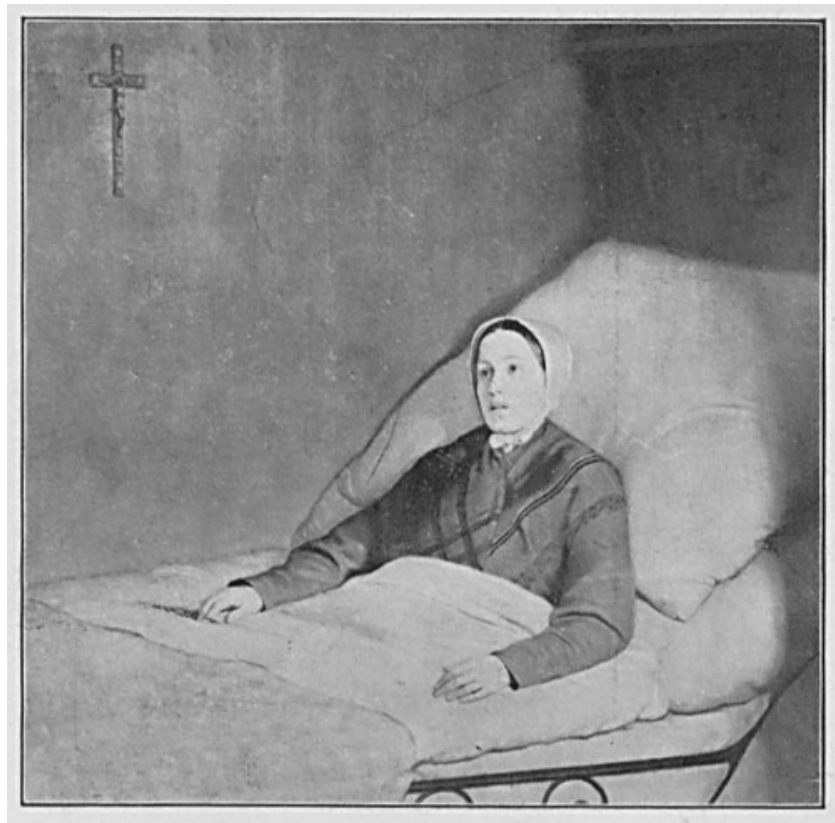

Figure 4. Postcard of a painting of Louise Lateau by Alexandre Thomas, April 1876 , Ruusbroec Institute, Antwerp, RG-PC Angels/saints/blessed souls: Lateau 1.

condition, but had not used that image for his official painting. 37 Thomas knew that whenever relics were brought close to Louise, her features contracted, and the painter preferred not to depict her in such a condition. $3^{8}$ The sober and calm setting of the portrait of the 'holy girl' ('sainte fille') seems to have been appreciated by the public as well. Thomas was believed to have painted the 'heavenly face' 39 wonderfully and the 'angelic figure of she whom one might in future invoke as a saint'. $4^{\circ}$

How can the bishop's commissioning of a painting of Louise Lateau, as well as his granting permission for the photoshoot, be reconciled with his response to the photographs? From his first response to Fr Niels onwards,

37 The painting had been on display in Thomas's studio, was seen by many, and elaborately commented upon in the newspapers of the day: Paul Vrignault in Courrier de Bruxelles, 19 Apr. 1876, and P.V. (probably Paul Vrignault), in Le Monde, 20 Apr. 1876. Alexandre Thomas was born in Malmédy in 1810. He studied in Düsseldorf and Antwerp and painted Louise from 1 to 21 April 1876: Lily Verbelen and Dominique Speeckaert, Alexandre Thomas (I8IO-I898), portraitiste, peintre d'histoire et de sujets religieux, n.p. 1997 .

$3^{8}$ Middelburgsche Courant, $3^{1}$ May 1876, 3 .

39 Cutting of an article from the Courrier de Bruxelles (1876?), ALL, J.10, I.10.

40 P. V., Le Monde, 20 Apr. 1876. 


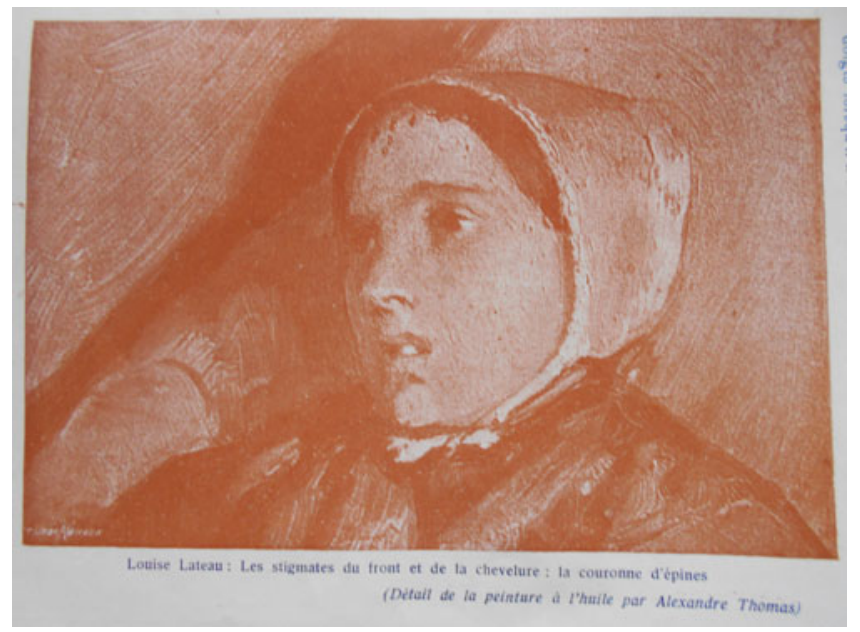

Figure 5. Print of a smaller painting of Louise Lateau by Alexandre Thomas: Almanach National Belge Notre Dame de Lourdes, Louvain 1914, 53.

there are references to the Holy See demanding the retraction, with the bishop of Tournai only echoing their demand. $4^{1}$ Rome was always very careful in these matters and wanted to deflect from these exceptional souls anything that "might obscure divine action or be open to malicious interpretations'. $4^{2}$ As Dumont noted, 'Everything was premature and untimely'. 43 What happened in Louise's case was in fact similar to the measures taken in 1924 by the head of the cloister of San Giovanni Rotondo in the case of Padre Pio (1887-1968). He forbade pictures being made of the Italian stigmatic in order to avoid the accusation of the commercialisation of the cult. 44

Thus, there was an immense difference between a painting that could be kept safely behind the closed doors of the episcopal palace and photographic negatives which could be reproduced endlessly, were difficult to monitor and easy to exploit. Apparently, the whole painting commission

$4^{1}$ Hallez to Ducoulombier, 26 Oct., 3 Nov. 1877 , ALL, A.6, cahiers, 1877 ; see also 220.

$4^{2}$ 'tout ce qui pourrait obscurcir l'action divine et prêter à de malignes interprétations': ALL, B.4, documentation diverse, 8, 'Affaire des photographies représentant Louise Lateau', Mr l'Abbé Ducoulombier, $1877-8$, letter dated 2 Jan. 1878 .

43 'Le tout est prémature et intempestif': copy of the letter from Dumont to the archbishop of Cambrai (whose jurisdiction Ducoulombier was under), ALL, A.6, cahiers, $1877,220$.

${ }^{44}$ Urte Krass, 'Kontrollierter Gesichtsverlust: Padre Pio und die Fotografie', Zeitschrift für Ideengeschichte iv/ 2 (2010), 71-96 at pp. 76, 80. 
had been simply an attempt to hinder the plans of Cardinal Dechamps to have a portrait made and thereby to avoid any misuse of such a painting by others. 45 Canon A. Thiéry cites the following explanatory note that Dumont published in La Vérité on 25 June 1880 :

The cardinal [Dechamps] has always been one of the great admirers of Louise Lateau. He even wanted the portrait of Louise Lateau to be made despite her wishes. So, to avoid the portrait of this girl being exhibited, I was obliged to have it painted myself by the painter Thomas. I have always kept it hidden, even though I paid 4000 fr. for it. I have never published a line about Louise Lateau and I have ordered the priest to suppress the photographs of Louise. $4^{6}$

That Dumont had permitted the photographs was conveniently omitted. In Thiery's biography, it is primarily Dechamps who seems to have been eager to promote Louise and who convinced Alexandre Thomas to put his painting of Louise on display in his studio on the Rue du Commerce in Brussels. Apparently, numerous people came to see the painting even before Thomas handed it over to the bishop of Tournai.47 Interestingly, Marie and Pauline De Beukelaer also had the painting photographed (by a photographer named Boisson) even before it left Bois-d'Haine. Their letters document how careful they were not to allow the negatives out of their sight - only two prints were to be made: one for the bishop and one for Niels. $4^{8}$ In fact, some photographs connected to Louise had already been sold for profit in Boisd'Haine. These featured the church of Bois-d'Haine and the house of the Lateau sisters. What seems to have been particularly distressing for Dumont is that they were sold by the 'vendor of the bad newspapers' ('crieur des mauvais journaux'). 49

Admittedly, Thiéry paints a rather black-and-white picture of the cardinal and the bishop of Tournai, but it is clear that the bishop accused Lorleberg and the others of exploitation and unwanted publicity. When Ducoulombier attempted to explain the bishop's reasons for banning him from Bois-d'Haine, he stated that he believed that Bishop

45 Victoire-Auguste Dechamps was appointed archbishop of Mechelen in 1867 and cardinal in 1875 .

$4^{6}$ 'Le Cardinal (Dechamps) a toujours été l'un des grands admirateurs de Louise Lateau. - Il a même voulu que le portrait de Louise Lateau fût fait malgré elle, et pour éviter qu'on exposât le portrait de cette fille, j'ai été obligé de le faire faite moimême par le peintre Thomas. Je l'ai toujours tenu caché, bien qu'il m'ait coûté 4000 fr. Je n'ai jamais publié une ligne relativement à Louise Lateau, j'ai ordonné à M. le curé de supprimer les photographies de Louise': Armand Thiéry, Louise Lateau de Bois-d'Haine: à propos du livre publié par le père Lejeune sous le titre 'La vie du Père Huchant', Liège 1914, 94-5. $\quad 47$ Ibid. 92. $\quad 4^{8}$ ALL, A.6, cahiers, $1876,95$.

49 Notes on Lorleberg and Louise Lateau, ALL, B.5. 6. 
Dumont had an idée fixe 'that we wanted to exploit photography and put a print to one side to use according to our needs'.$^{\circ}$ Pleading his friend's case, Fr Niels wrote to the bishop several times, and while he agreed that they had indeed taken a lot of photographs of Louise, he noted that they had only done so because they did not know whether they were going to be successful. He claimed that they had never intended to exploit them and while he had indeed sent photographs to Ducoulombier this was only a temporary loan, to enable him to finish his report on the photoshoot. $5^{1}$

However, a letter of 25 October 1877 from the Jesuit Provincial, Joseph Janssens (Lorleberg's superior), to Bishop Dumont hints at something slightly different. Janssens describes how Lorleberg had gone to Boisd'Haine a few days before with the photographs of Louise Lateau and was planning to travel to Tournai to deliver them to the bishop. Fr Niels, however, convinced him not to go because the bishop was on his way to Rome and took delivery of the photographs himself:

Since then he has asked for new copies for benefactors. As I think that one has to be very cautious in this affair, I told Father Lorleberg to go to Tournai as soon as possible, to talk to your Highness, and offer him the photographs. If your Highness cannot receive him tomorrow, perhaps he would be so kind as to ask one of the Vicar Generals to do so. The pastor of Bois-d'Haine might keep a copy, but I fear that the photographs might be circulated and exploited..$^{2}$

Bishop Dumont acted accordingly. But why did he allow the photoshoot to take place in the first place?53 The primary reason seems to have been that it was in order to document the case. On 7 April 1876, during Alexandre Thomas's painting sessions, Fr Niels expressed his trust in the good outcome of the painting, but signalled to the bishop the aspects that they were missing out on: 'The portrait of Louise will be well done, but it will be a great loss not to have her portrait whilst in ecstasy. For this, one

$5^{\circ}$ 'que nous avons voulu exploiter la photographie et mettre en réserve une petite épreuve pour nous en servir au besoin: c'est une idée fixe': Ducoulombier to Niels, 9 Mar. 1878, and 19 Nov. 1877, ALL, B.4, documentation diverse, 8, Affaire des photographies.

$5^{1}$ Niels to Mgr [Dumont], 12 Dec. 1877, ALL, A.6, cahiers, 1877, 223-4.

$5^{2}$ 'Depuis il demande de nouveaux exemplaire pour des bienfaiteurs. Comme je pense qu'il faut être d'une très grande réserve dans cette affaire, j'ai fait dire au Père Lorleberg d'aller le plus tôt possible à Tournai, pour en parler à Votre Grandeur, et Lui offrir des photographies. Si V.G. ne peut le recevoir demain, qu'Elle veuille en charger un des M. M. les Vicaires Généraux. Mr. Le curé de Bois-d'Haine pourrait bien garder un exemplaire, mais je redoute la propagation et l'exploitation': Jesuit provincial, Joseph Janssens SJ, to Dumont, Archives of the diocese of Tournai, J/3/10, files related to parishes, Bois-d'Haine.

53 As noted by Niels: ALL, A.6. cahiers, $1877,218$. 
would absolutely need to use photography.' $54 \mathrm{He}$ did not seem to be aware of the permission that the bishop had already granted to Marie and Pauline De Beukelaer in February 1876. His letter, however, illustrates the documentary intention of the photographs - this reason was repeatedly emphasised by Niels and his colleagues in their apologetic reports. Niels only wanted one print of each negative to be kept in the parish archives to document the case for future generations 55 and opened his report on the photographs with the following note: 'the religious authorities wanted for some time to capture with photography the features of Louise Lateau, so often transfigured by ecstasy, and capture forever her expression during the incomparable scenes on Fridays' $.5^{6}$

\section{Louise's image}

Lorleberg and Ducoulombier considered their photographic mission to have been a success, because God, 'the divine photographer', had helped them by sending them the right lighting conditions. 57 They had succeeded in taking advantage of rapidly evolving photographic techniques to capture Louise in ecstasy, and they lauded the beauty of these moments. Nevertheless, a certain unease seems to have lingered, with Lorleberg explicitly stating his preference for the photographs of Louise in a natural state. A similar preference is to be found in the work of Alexandre Thomas, whose painting depicts Louise in a calm, contemplative state, although he had also managed to paint a smaller picture of her in ecstasy. It is interesting to note that even this painting would be 'toned' down. In a drawing based on Thomas's painting, which was published in 1891 in a book on Louise and other stigmatics, the slightly open mouth in the original is no longer open at all (see fig. 6). $5^{8}$

Louise's image was indeed distributed despite all attempts at control. It is unclear when and by what means it began to be circulated, but as early as 1885 (two years after her death), a portrait based on Thomas's painting was included in Souvenirs de Bois d'Haine. Variations on the painting can also be found on devotional cards in honour of Louise Lateau (notoriously difficult to date). Moreover, even the portrait pictures, and particularly the one that Lorleberg thought best captured Louise's saintly character, can be found on devotional cards (

54 'Le portrait de Louise sera bien fait, mais il y aura une grande lacune de n'avoir pas son portrait pendant l'extase. Pour cela il faudrait nécessairement se servir de la photographie': copy of Niels to 'Mgr' [Dumont], ALL, A.6, cahiers, 1876, 72.

55 ALL, A.6, cahiers, 1877 , 224.

57 Ibid.199. See also 195, $217,205$.

$5^{8}$ A.J. Riko, Louise Lateau en andere mystieken: met afbeeldingen en volledige lijst der gestigmatiseerden van I 86 tot op onze dagen, Amsterdam 1891 . 


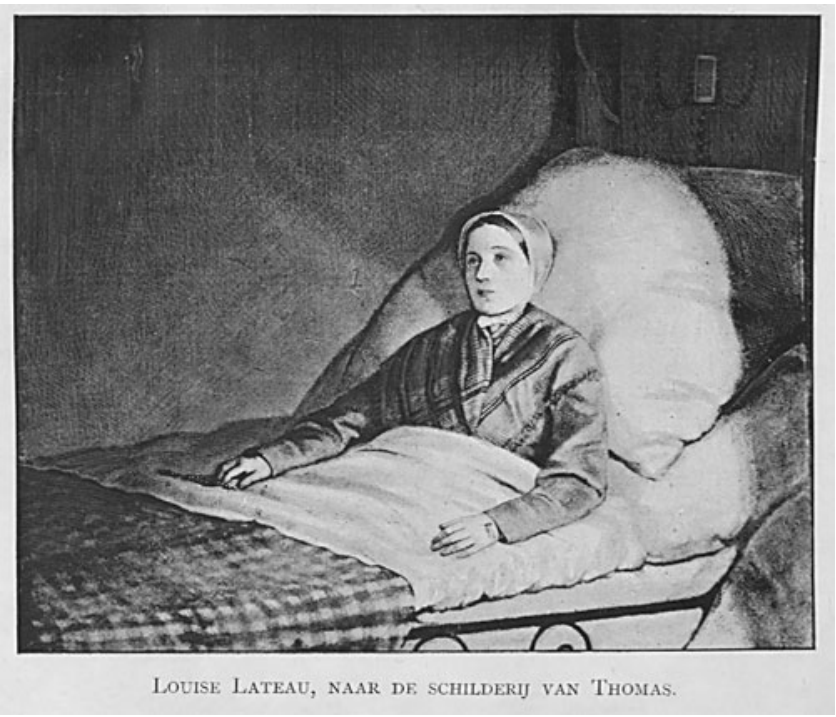

Figure 6. Drawing based on the larger painting by Alexandre Thomas: Riko, Louise Lateau en andere mystieken, frontispiece.

made it into the public realm were just like the photographs of Bernadette, each one 'a safe and controllable image'.59 In fact, those involved in the 1877 affair seem only to have distributed the 'natural' photographs among their friends. ${ }^{60}$

The image that these devotional cards and book illustrations create of Louise is thus a slightly 'filtered' version. Her stigmata are barely present, or covered by fingerless gloves. The effect is an image of controlled, calm prayer, rather than uncontrolled and uncontrollable ecstasy. The limited importance attached to the stigmata in these pictures was in line with the Vatican stance on stigmata. Considered to be epiphenomena, they were never in themselves sufficient reason to be declared a saint. On the contrary, they made stigmatics vulnerable to accusations of hysteria and fraud, as the status of these phenomena was no longer considered incontestable by the Church. ${ }^{61}$ Nevertheless, such sober visual representations cannot be considered the dominant or only style of representation of stigmatics.

59 The pictures were to cultivate 'a safe and acceptable image of Bernadette as an obedient yet stalwart peasant visionary': Suzanne Kaufman, Consuming visions: mass culture and the Lourdes shrine, Ithaca-London 2005, 24.

6o On 14 October 1877 Lorleberg went to Bois d'Haine to give the Lateau sisters some preliminary versions of the photographs, 'in a natural state of course' ('au naturel bien entendu'): 'Mémoire sur les photographies de Louise Lateau', ASJF, 30.

61 'In fact, canonization processes do not consider stigmatization a miracle because it does not meet the requirement of being incontestable': Emily Moerer, 'The visual 


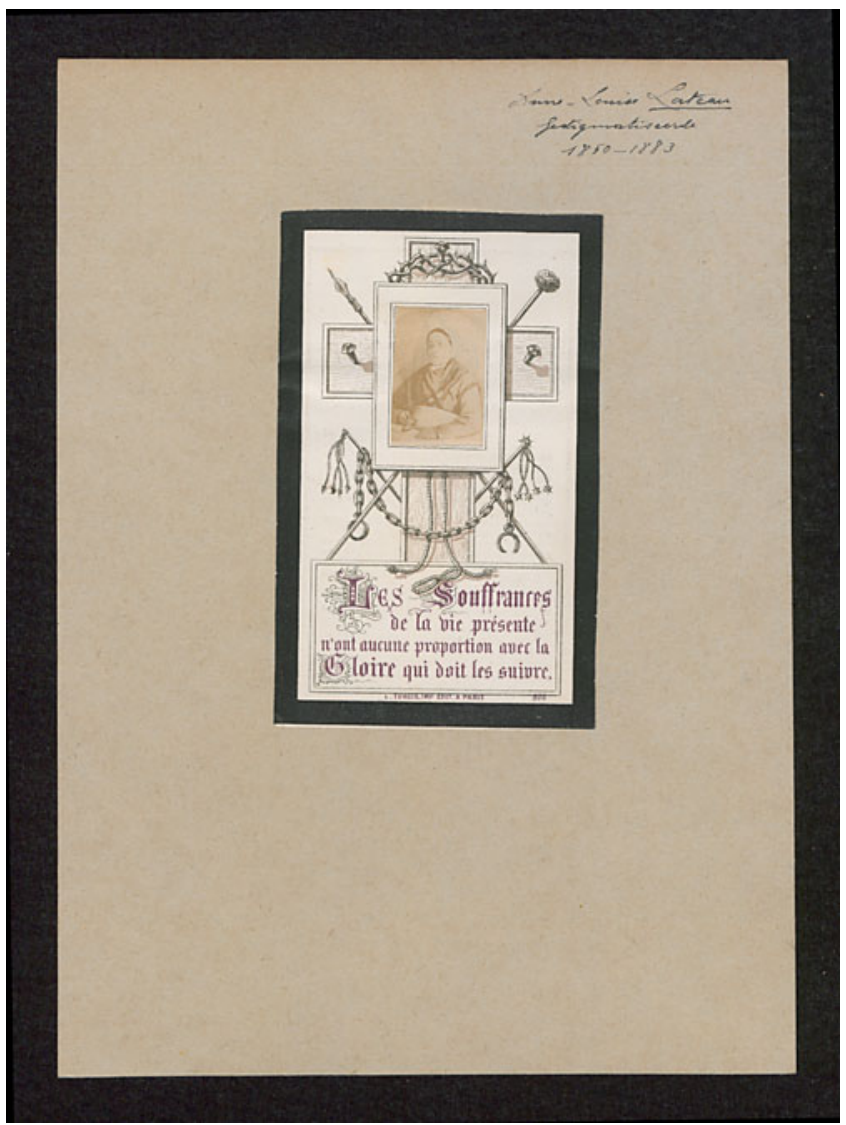

Figure 7. Devotional card of Louise Lateau, Ruusbroec Institute.

If Louise's pictures are compared with with those of two other, younger, Belgian lay stigmatics - Rosalie Put (1868-1919) and Clara Jung (1887$195^{2}$ ) - it is clear that their bloody images were distributed widely and seemed to function as a kind of additional confirmation of the truth of their stories. In Clara Jung's case, one of her devotional cards features the stigmatic with her face covered in blood, while pictures of Rosalie Put reproduced in German and Dutch texts show her in ecstasy, with a blood-smeared face and clutching her rosary. Similar, bloody images of older stigmatics were also circulated. ${ }^{62}$

hagiography of a stigmatic saint: drawings of Catherine of Siena in the Libellus de Supplemento', Gesta xliv/2 (2005), 89-102 at p. 97.

${ }^{62}$ See, for instance, the cards of Clara Jung preserved at the Ruusbroec Institute: Ruusbroec Institute, Antwerp, RG-PC Angels/saints/blessed souls: Clara Jung (20 
The devotional cards featuring Louise Lateau offer a particular set of sources in this regard. One of the oldest cards features an image based on Thomas's painting, thus, a rather sober style of representation. The picture is, however, positioned at the centre of a crucifix, surrounded by the instruments of torture that cause the stigmata, and is thus a clear reference to the latter. Similarly, a devotional card depicting Louise - with an imprimatur of 1938 and a plea to contact the pastor of Bois-d'Haine should a favour be obtained through the mediation of Louise - included Lorleberg's 'saintly' image. ${ }^{63}$ On the back, however, one of the first lines states that Louise was stigmatised. Thus, while the stigmata seem to have been regarded as of little consequence at the Vatican level, they were certainly of central importance in the initial promotion of the cult. In the case of Louise, hints about the wounds were linked to an aestheticised, incontestable image of Louise.

The ecstasy pictures and smaller painting seem to have been lost from view for some time, until an article featuring them was published in the Almanach National Belge Notre Dame de Lourdes in 1914, with the title 'Unpublished portraits of Louise Lateau'. The introduction to the article claims that while the portrait commissioned by the bishop(s) was well known, Alexandre Thomas had also created a smaller portrait 'for his own edification' (see fig. 5). The Almanach included a painting which was unpublished at the time, in which Louise displayed the wounds originally inflicted upon Christ by the crown of thorns. Lorleberg's ecstasy pictures also featured extensively and the readers were guided on how to understand them: 'Her [Louise's] expression is earnest and pained, her arms are extended by compassion like those of someone who is crucified. One can observe in all her features the deepest consternation and the pity that faithfully shares in the pains of the crucified. ${ }^{64}$ Interestingly, the pictures of Louise in ecstasy feature on some even later devotional cards (with an imprimatur of 1938 and 1974 , but probably printed more recently: see fig. 8).

May 1952) (featuring photographs of Clara with and without blood on her face) and Rosalie Put: Robert Ernst, Rosalie Put uit Lummen, gestigmatiseerde van de XXe eeuw, I 868-I9I9, Mechelen 1953, photographs of the early twentieth century included at the back. On the older stigmatics see, for instance, the pictures kept at the Wellcome Institute, London: <http://blog.wellcomelibrary.org/201 1/o4/visiting-the-stigmaticsof-the-south-tyrol-i-maria-domenica-lazzari/>.

63 Ruusbroec Institute, RG-PC Angels/saints/blessed souls: Lateau 1.

64 'Portaits inédits de Louise Lateau', Almanach National Belge Notre Dame de Lourdes, Louvain $1914,52-6$. The procedure with the water for ablution is described in detail, with the small difference that the whole undertaking (photographs and triggering the ecstasy) is presented as Lorleberg's doing: 'Son expression est tout grave et douloureuse, ces bras se sont étendus par compassion comme ceux d'un crucifié. On remarque sur tous ces traits la consternation la plus profonde et la pitié fidèle à partager les douleurs du crucifié.' 


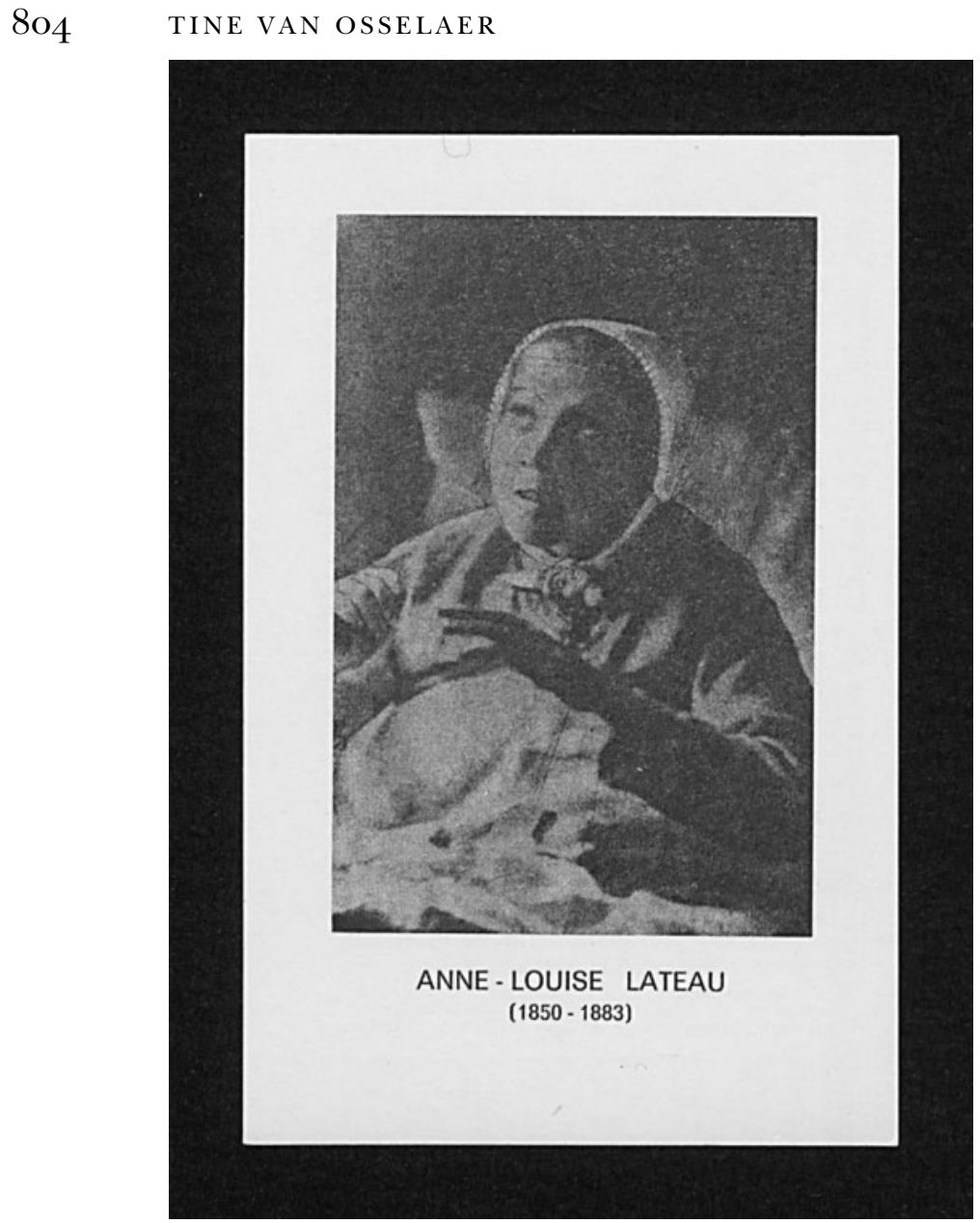

Figure 8. Devotional card of Louise Lateau, Ruusbroec Institute.

Did the episcopal authorities of the Tournai diocese develop a more positive stance towards Louise after her death? Is that why such cards can now be traced? In reality, a positive evaluation had already begun during her lifetime. Even Bishop Dumont was convinced of her saintly character - at least that is what Ducoulombier reports. The Tourcoing priest did not give up visiting Louise without protest, and in late February 1878 he went to see Dumont. The visit was not very successful as Ducoulombier only obtained permission to photograph Louise after her death. In a letter to Niels, he notes that the bishop was very kind, and that the 'Monseigneur is full of admiration for Louise and regards her as a saint. He will take care after her death of everything that the law prescribes on 
such an occasion. ${ }^{65}$ By the time that Louise died, however, the situation had changed completely, with Bishop Dumont removed from his position and forbidden from seeing Louise (or 'counselled' not to do so) ${ }^{66}$ Dumont was actively involved in the School War which was being waged throughout Belgium at the time (1878-84), creating numerous religious schools.

At this point, tensions between ultramontane and liberal Catholics were also on the rise as well. While Cardinal Dechamps had good connections with the liberal Catholics but did not oppose ultramontane actions as actively as his predecessor had done, Dumont became an eager promotor of the ultramontane faction. ${ }^{67}$ His combative stance and nervous disposition eventually led Pope Leo xIII to intervene and retract Dumont's jurisdiction in November 1879 and his title in 1880. Any hint of an understanding between Louise and Dumont could taint her reputation, as could her alleged disobedience to the new bishop, Isidore-Joseph $\mathrm{Du}$ Rousseaux. In 1905 a 'mémoire justicatif' was published by Niels, which reiterated that the public assaults on Louise's person arose because of her ties with Dumont. ${ }^{68}$ Thus, by a strange turn of events, the bishop who had once banned others from visiting Louise and claimed that this was to protect her reputation, was now himself banned and a danger to her reputation. However, both his active interference in the photography episode and the later discussions of his continuing visits to Louise reveal that the reputation and public image of a stigmatic were carefully monitored. The people involved in this particular affair did not underestimate the importance of an untainted, carefully constructed and monitored image. For there to be any chance of them aspiring to more, the 'saintto-be' would have to leave this world with an untarnished reputation.

\section{Sanctity in the making}

Both Dumont and Dechamps thus appear to have had faith in events in Bois-d'Haine, despite Dumont's actions seeming to suggest the opposite.

\footnotetext{
$6_{5}$ 'Monseigneur est plein d'admiration pour Louise et la regarde comme une sainte. Il songera après sa morte à tout ce que le droit prescrit en pareille occasion': Doucolombier to Niels, 1 Mar.1878, ALL, B.4, documentation diverse, 8, affaire des photographies. Ducoulombier only received permission to return in August 1878: Niels diary entry, ALL, A.6, cahiers, $1878,103$.

${ }^{66}$ On the conditional 'consultation' of the new bishop, Du Rousseaux, to refuse the visits as long as Dumont continued to rebel against the pope, translated as 'order' by Niels, see Thiéry, Louise Lateau de Bois-d'Haine, $5^{67}$.

${ }_{7}$ Karel Van Isacker, Werkelijk en wettelijk land: de katholieke opinie tegenover de rechterzijde, Antwerp 1955, 208-10; Henk De Smaele, Rechts Vlaanderen: religie en stemgedrag in negentiende-eeuws België, Leuven 2009, 200-1.

68 Louise Lateau et Mgr Dumont: mémoire justificatif, publié par abbé Niels, Louvain 1905.
} 
In a period in which the tensions among liberals and Catholics were rising and in which one would have expected him to support popular religious dynamism, Dumont intervened in a case that, for many, was physical proof of God's presence in the world, a symbol of hope to Catholics (of all nationalities, who felt oppressed. Interestingly, Dumont interfered precisely because he believed in Louise Lateau and did not want to diminish her chances of beatification, if not canonisation, after her death. Impeding the circulation of her portrait (and any profit that might be made out of it) countered all accusations of commercialism and publicity that might jeopardise Louise's case in the future. At the same time, however, posthumous official recognition could only occur if people knew about Louise and if her case was well documented. Visits to her house were not therefore prevented, Thomas was given the commission to paint her, and the photoshoot was authorised to provide visual proof of the ecstatic episodes that painters had difficulty depicting. The pictures provided documentary 'proof' of Louise's ecstasy - albeit staged - visualising the exceptional corporeal phenomena as the basis for Louise's claim to mystical powers and even sanctity. Nevertheless, while Lorleberg and Ducoulombier succeeded in taking what they believed to be the first pictures of someone in ecstasy, it is telling that these were not the pictures that Niels and his friends decided to circulate among their friends. Only the portraits showing Louise in a calm state were used to promote her image. This distribution of the pictures, however - albeit on a limited scale - alarmed the ecclesiastical authorities. Whatever possibilities photography created, it also had a downside, as it was a medium that was difficult to control: several copies of one photograph could be produced without much effort or cost. Thus, half a century before Padre Pio's photographs were banned, Louise's pictures were recalled and most were destroyed. Luckily, however, that intervention was not a complete success and the images survived. 